\title{
Stimulating black entrepreneurship through training: a case study in development
}

\author{
B. Mokoatle and H.L. Prekel
}

Economic problems and threatening food and energy shortages, together with the contrast and polarization between the developed and underdeveloped countries, have brought the world to the brink of a crisis. The development of selfreliance and entrepreneurship among the poorer communities could contribute to solving the above problems. Several barriers need to be overcome to stimulate black entrepreneurship in South Africa, one being the need for specialized business management training. The paper describes as a case study the Small Business Management Programme introduced in 1975 by the School of Business Leadership of the University of South Africa. A progress report on the course is given, with fairly high success rates in terms of both academic and business achievement. Of particular interest is the wide range of projects (business viability studies) investigated by students as a course requirement, several of which have been implemented as successful business ventures.

S. Afr. J. Bus. Mngmnt. 1979, 10: 23-28

Ekonomiese probleme en dreigende voedsel- en energietekorte, saam met die kontras en polarisering tussen die ontwikkelde en onderontwikkelde lande, het die wêreldgemeenskap tot op die rand van 'n krisis gebring. Die ontwikkeling van selfstandigheid en entrepreneurskap onder die armer gemeenskappe kan grootliks bydra tot die oplossing van bogenoemde probleme. Verskeie struikelblokke moet oorkom word om swart entrepreneurskap in Suid-Afrika te stimuleer. Een hiervan is die behoefte aan gespesialiseerde sakebestuursopleiding. Die artikel beskryl as 'n gevallestudie die Kleinbesigheidbestuursprogram wat die Skool vir Bedryfsleiding van die Universiteit van Suid-Afrika in 1975 ingestel het. 'n Vorderingsverslag word oor die program gegee, waarin redelike hoè akademiese sowel as sakeprestasies aangedui word. Veral van belang is die wye reeks projekte (uitvoerbaarheidstudies van sakeondernemings) wat studente as 'n kursusvereiste ondersoek het; verskeie van hierdie projekte is intussen as suksesvolle ondernemings in bedryf gestel.

S.-Afr. Tydskr. Bedryts!. 1979, 10: 23-28

B. Mokoatle and H.L. Prekel*

School of Business Leadership, University of South Africa,

P.O. Box 395, Pretoria 0001
The events of recent years, notably soaring food prices, the energy crisis, the combination of high inflation rates and global economic slow-down, have brought the world to the brink of a crisis at the close of this century. Prospects for the future are uncertain. Powerful industrial countries are bemoaning the world population explosion in the face of dwindling world raw material resources. They are rightly concerned about the poorer countries' inability to produce enough food to feed themselves. They are concerned about the declining productivity and crippled economies of poorer countries. They are busy devising ways and means of consolidating and maintaining the progress and material wellbeing of their people. Poorer nations are preoccupied with adapting to a technological world order, and in the process are getting left far behind and becoming poorer still.

A crisis is looming as the century draws to a close. The crisis is the polarization between developed and underdeveloped countries or regions; between powerful industrial countries and weak non-industrial countries; between the rich and the poor; between the haves and have-nots. Although the have-not countries may be richly endowed with natural resources, they seem to be incapable of exploiting these to the benefit of their nationals. In attempting to adapt to a technological economic order, the poorer nations frequently borrow economic models from advanced countries which they then apply without much impact, in a climate which militates against the success of such models ${ }^{1}$. Prophets of doom see prospects for the last quarter of this century as bleak for the poorer nations.

A complex of moral questions arises in the relationship between the advanced countries and the poorer ones:

- Should the natural resources in developing countries remain unused when other people in the industrial world community can turn these resources to practical account for the benefit of mankind?

- What is the moral obligation of those who are capable of exploiting these resources to those who are not capable of doing so?

- In seeking success for themselves, have the advanced nations failed to discharge their responsibility toward a global economic order which would serve the interests, material needs and progress of mankind?

- What is ailing the world economic system? Why are sec- 
tions of a population in the same nation or region poorer than others?

- What can the poorer nations or sections do to advance themselves and become economically active so that they are not counted among the poorer relatives in a world social order?

These are the questions to which answers have to be found in order to find a solution to the looming crisis of world-wide starvation.

The answer to the problem, at least for the poor sections of communities, apparently lies in self-reliance and regional economic development. This point of view recognizes that development must, in the final analysis, be traced to the specific actions of people who live in specific places and in specific cultures. It also recognizes a new mood in the black communities which promises to usher in new economic activities. That mood is the new philosophy of black consciousness seeking self-determination and automony for a people who have, for a long time, been economically less fortunate and dependent on others. It is a nationalism that, in South Africa, has found expression in the accumulation of capital to establish a black bank and other new business ventures. It is a nationalism that has found expression in autonomous strivings by specific people in search of human dignity through sustained effort.

The authors suggest that the promotion of entrepreneurship in the context of community development should be aimed at a level where action is feasible and results are attainable. But the stimulation of black entrepreneurship is not without problems. One sometimes marvels at the development of black entrepreneurs in situations, and under conditions which seem to negate all models for economic development and depress stimulation of entrepreneurial talent.

However, the stimulation of the black entrepreneur is feasible when:

- one recognizes the obstacles facing the development of the entrepreneurial talent and takes steps to break down the barriers;

- one understands the phychological dynamics and motivational patterns of the black entrepreneur;

- one tailors one's training interventions to suit the needs, peculiarities and unique personalities of the individual businessmen.

\section{Barriers to entrepreneurial stimulation and development among blacks in South Africa}

Arnold Schucter ${ }^{2}$ proposed a working model for industrial and business development which '... must reflect and support the need to build countervailing power, and consumer choice close to the point of consumption of goods, services and opportunities'. This model suggested, among other things: the creation of a viable ghetto-based (townshipbased) economy with tax credits and subsidies to firms (white) with majority black ownership; the creation of a national development bank to finance economic and industrial activities; a community development corporation to plan and channel proposals in the area; provision of greater tax benefits to white investors in black areas; and intensified and specialized training in business management.

Such a model appears to be a perfect blueprint for South African urban township economic development if it could be translated into a feasible action programme. It would achieve a low-cost transfer of technology through direct investment by government and private sector, joint venture and management agreements.

The applicability of such a model is doomed to failure unless the government fundamentally changes its attitudes and policies toward the urban black business community. It would also be doomed to failure unless certain conditions in the environment and psyche of the black man are drastically altered to be receptive to entrepreneurial stimulation. These conditions refer to the state of poverty, both real and pyschological, in both urban and homeland environments. Lee $^{3}$ pointed out that businesses do not prosper in a poverty environment for two main reasons: where there is poverty, demand is low; and the managerial and technical skills required to operate businesses are usually not found in such situations.

In most of the black townships in South Africa as well as in the homeland community settlements, the definition of a poverty environment applies as follows:

- most black families in the urban and homeland areas have limited sources of income, and most of them live at a subsistence level

- there is a deficiency of community resources and income substitutes. The unemployment rate is high, wage levels are low, skill composition is not sufficiently differentiated and business opportunities are limited (at least in the urban areas)

- there are poverty-linked demographic characteristics which negate economic stimulation, such as being black; heads of families being female or aged; large families with six or more children under 18 years; heads of families with less than eight years of education.

The most detrimental factor among all these is the presence of a culture of poverty attitude. Prolonged economic deprivation and social participation whilst observing the affluence of the other section of the population seem to have led the black man to a state of mind of feeling poor even though he has money and ability to act. This state of mind inhibits the will to act and creates a barrier to learning and self-improvement.

\section{The dynamics of the black entrepreneur}

Despite the bleak picture of black communities and their impoverished environments which we have painted above, certain individuals with the will to act have surfaced in defiance of the status quo and their situation. These are the true black entrepreneurs who, like any entrepreneurs the world over, have had a long and rigorous period of training. This training occurred between the time when the black youth or young adult left family life and whatever formal education he or she might have received - often little and the time they established themselves in business. Looking at the profiles of many of our black businessmen and -women - usually traders - one is confronted by the fact that a great majority of them had very little education. It is true, however, that the situation is now changing very rapidly.

These entrepreneurs are now going through an even tougher school of reality in which the curriculum is usually varied but rough. Those who graduate successfully are people of unusual ability, strength and courage. Many count their credits in lost jobs - they have been dismissed on a number of occasions or, having disagreed with employers, decided to venture out on their own. Some 
attempted to start up businesses early in life but failed. They are now back at it again. Many started peddling goods sweets and food items - at the age of 9,10 or 12; others have swindled their mentors or financiers and spent some time in the law courts. Peddling is often fun and exhilarating while it lasts, and when the tribulations are over and the business is established, the individual emerges finally as a seasoned entrepreneur, ready to discharge his or her responsibility as both a social and an economic change agent.

\section{Problems of teaching and training}

How can one teach and impart knowledge to entrepreneurs with such vast real-life experience and such wide selfacquired knowledge? It has been shown in many studies that entrepreneurs are very busy people. They are on their feet 16 hours a day, seven days a week. They think and decide on their feet as they go about organizing resources for their enterprises. Where can they find the time to scan through all the academic stuff offered by the university business school? Do they need all that information to make money in this business? Perhaps not. But they need to know and do certain things if their businesses are to be stable, if they are to grow and to expand. How then do they acquire this know-how?

\section{PROBLEM 1: 'If I have started it, I can manage it.'}

There is a saying that there are three types of entrepreneurs. These are the winners, the losers and the survivors. To be sure many black businesses find themselves in the category of survivors. Once in business, the financial naiveté of most entrepreneurs manifests itself in many ways. They may find that they have spent too much on capital improvements, leaving insufficient funds for adequate inventory. Overheads bewilder them, they may not be able to assess the state of health of their businesses - the ability to meet its liabilities or commitments; they may not be able, or even bother to separate their business assets from their personal finances. Perhaps this results from the ancient black philosophy of holism. Frequently, there is inability to differentiate between the owner's rights on the business and the business as a legal entity. 'I am the business and the business is me.'

\section{PROBLEM 2: Management skills}

Small business owners are headstrong adventurers. Since they are self-employed, they want to do things their own way. Yet, when you ask these entrepreneurs what their greatest business problems are, they will tell you: 'People'. Advice regarding the principles of personal management is spurned as academic conceptions suitable for non-practical university students.

\section{PROBLEM 3: Business opportunities and getting started}

Many potential and aspirant entrepreneurs are unable to get started or figure out what they must get started on. This uncertainty is not only peculiar to the aspirants, but also to practising businessmen who want to expand their current businesses because they are experiencing a 'systemsoverload'.

Any business school can teach finance, accounting and bookkeeping; personal finance; business law; personnel management and other related business management courses; but a sensible way to penetrate the defensive armour and attitudes of small business managers is to convert or transform these academic principles into operational behaviour in a real business. These principles must be turned into the habitual behaviour of the entrepreneurs as they go about their daily routine.

It is suggested, therefore, that any programme aimed at the stimulation and development of black entrepreneurs should be pitched at a level which will enable the entrepreneurs to learn by doing. They should get the shock of inaptitude. It should be pitched at a level where black entrepreneurs will be able to recognize business opportunities and want to seize them. They should constantly be thinking of diversifying and multiplying. After all, the viability of the black economy rests squarely on their shoulders and depends on what they do. The projects undertaken during such a programme as assignments should sharpen their senses.

The approach of the programme should focus on the five senses of the businessman:

- He should see his own weaknesses. By applying financial devices in his own business, he should read and see his own and the position of his business through sales records, balance sheets, operating statements and a variety of ratios. Let him get a shock.

- Let him hear from his customers, employees, creditors, bankers, suppliers, how he rates as a businessman. Let his ego be boosted or diminished as necessary.

- Let him smell trouble through analysing his own financial statements. Let him make all the excuses possible. Let him smell trouble through the expansion plans he has drawn up.

- Put him in touch with a wider circle of businessmen.

- Let him taste success through interacting with others in his field. Revive the economic use of the entrepreneurial motive.

The approach should merge academia with the greater community, the real-world laboratory situation which produces an exchange of ideas that will enrich both the entrepreneur and the citizen. The focus should be on the individual.

Small businesses have certain advantages, and black entrepreneurs are faced by new challenges and opportunities. If these advantages, this black consciousness, can be turned into a multiplicity of small but economically viable units in an enriched environment, then there need be less concern about the spectre of world-wide starvation in the last quarter of this century.

\section{The Small Business Management Programme (SBMP)}

The Small Business Management Programme which was introduced by the School of Business Leadership of the University of South Africa in 1975, is an example of an attempt to solve the problems mentioned above, by providing training and management development opportunity to black entrepreneurs.

The University of South Africa (UNISA) is well-known as a leader in the field of 'teletution'-teaching at a distance. Students are mostly mature working people, living in all parts of South Africa and even in other countries.

The SBMP is a 15-month course of teaching by correspondence, classroom lectures and case studies during study schools, group discussions among the students themselves, and visits by lecturers to student groups throughout South Africa to assist them with their studies and discuss prob- 
lems with them. The programme is primarily aimed at small business owners/managers, junior and middle level managers employed by large organizations, as well as other persons interested in starting and running their own businesses. Although the course was designed with black entrepreneurs in mind, it is open to people of all races, and undertakes to introduce the participants to the various areas of business management. The aim is to do this in such a way that students the become aware of, and understand the relationships between the management functions of planning, organizing, directing and controlling, and the different subject areas which make up the field of business management.

With this goal in mind, sequencing of lessons is undertaken rather than dealing with the subject matter in blocks. This approach also permits full exploitation of one oof the biggest advantages of UNISA's system of teletuition, the fact that all participants are in employment while studying and can therefore immediately and throughout their studies apply their knowledge to their own work situation. The SBL's study material, lectures and case study methods are all designed to further this integration of theory and application. For example, wherever possible, assignments which students must complete and send in for marking are set in such a way that students must identify and solve problems which exist in their own companies or businesses. Feedback is supplied via comprehensive written comments on each assignment.

Finally, the aspect of study groups merits some discussion. The SBL only accepts a student if he or she can join or get together a group of five to eight others studying the same programme. Since management is in essence a group activity, the SBL strongly believes that studying in a group setting is of great benefit. This is substantiated by research over the years which has shown that students belonging to well-functioning groups do better in the examinations and in applying what they learn, than others. The aim is always to set up groups in such a way that members come from different functions or disciplines, such as finance, marketing, production, and personnel, so that they resemble as closely as possible an actual management team. This provides a substantial amount of cross-fertilization of ideas, knowledge and opinions and thereby reinforces the understanding of the interrelationships among the various management functions. It is believed that group study is the major key to the SBL's success as a business school.

\section{Structure of the Small Busineas Management Programme}

The course is divided into nine modules and consists of 138 lessons. The nine modules are as follows, with the number of lessons in each in brackets: Management Process (18), Marketing (13), Finance, Accounting and Bookkeeping (44), Personnel Management (17), Business Law (17), Personal Finance (7), Business Communication (5), Production Management (10), and Office Procedures (7).

These modules are divided into four cycles corresponding to the study periods between four one-week study schools when all students travel to a central location for combined lectures.

\section{Topics}

Management process and office procedures
The individual and organizations

Management and small business management

Success and failure in business

Management functions: planning, organizing, directing and controlling

Business and the community

Business ethics

\section{Marketing}

The market

Sizing up the market opportunity

Products and services

Middlemen, purchasing, stockkeeping

Setting prices

Promotion, advertising, salemanship and merchandize

display

Analysing the market

Finance, accounting and bookkeeping

Starting and applying a bookkeeping system

Sources of funds

Salaries and wages

Depreciation and year-end adjustments

Income tax

Analysis and interpretation of financial statements

Cash flow analysis and budgets

Family and personal money management

Personnel management and business communication

The individual in organizations

Styles of leadership and morale in your business

Recruitment, interviewing, selection and training

Motivation and performance appraisal

Communicating with employers

Discipline

Pay plans

Labour relations

Production management

Product decisions

Plant location

Plant layout and work simplification

Equipment

Quality control

Production costs

Break-even analysis

Planning and scheduling production

Business law

Introduction to business law

Different forms of business organization

Contracts

Leases and mortgages

Insolvency

Bills of exchange

Service contracts

Wills and estates

\section{Assignments}

Written individual and group assingments are set by lecturers in the different subject areas. These cover both theoretical work and practical application. 
months of the duration, each group has to work through the complete process of planning a new business. The requirements for the project are to describe the venture and state its objectives; to draw up a business plan which would convince a venture capitalist or banker that the project is a viable proposition in which to invest money, and to turn these plans into practical account by starting up and operating the business if it is found to be feasible.

These projects are taxing exercises requiring dedication and hard work, but their usefulness and value lie in the fact that they force participants to think in a disciplined way in order to minimize uncertainty. They also compel students to apply the principles of management and the knowledge which they acquire in the course, to a live business venture.

With enrolments for the 1978/79 programme which started in August 1978 at 69, the steady increase in participants is gratifying and can be taken to reflect both the value of the programme to blacks, and the increasing business opportunities which are becoming available to them, as is evident from the figures in Table 1.

Table 1 Summary of results achieved by the SBL's Small Business Management Programme and its participants

\begin{tabular}{lrrrr}
\hline & $1975 / 6$ & $1976 / 7$ & $1977 / 8$ & $1978 / 9$ \\
\hline Enrolments & 27 & 34 & 56 & 69 \\
Owner/Managers & 15 & 20 & 29 & 28 \\
Employees & 12 & 14 & 27 & 41 \\
Wrote examinations & 22 & 25 & 43 & $*$ \\
Passed & 20 & 24 & $*$ & $*$ \\
\hline
\end{tabular}

Pass Rate:

\begin{tabular}{lllll} 
\% of enrolments & 74 & 71 & - & - \\
$\begin{array}{c}\text { \% oxamination } \\
\text { candidates }\end{array}$ & 91 & 91 & - & - \\
\hline
\end{tabular}

-In progress

Several interesting aspects can be mentioned in addition to these statistics:

\section{Pass rates}

The pass rates compare very favourably with those of the other degree and certificate programmes of the SBL, and are extremely good for part-time study. Two main reasons are advanced for this: the above average motivation of the generally underprivileged student to learn and do well, and to utilize new opportunities, and the extra effort put into this programme by the SBL and its lecturing staff, to the extent of inviting visiting professors such as Professor Albert Shapero, formerly of the University of Texas at Austin, and Professor David McClelland, formerly of Harvard, who are experts in entrepreneurship, to teach SBMP students.

\section{Women on the programme}

The proportion of women on the SBMP is generally higher than on the other programmes of the SBL. Smit ${ }^{5}$ takes this to be a cultural phenomenon, considering that women in underprivileged societies are brought up to accept the fact they have to be economically active, and the South African migrant worker system and other cultural factors frequently result in one-parent families with the responsibility for the economic well-being of the family resting with the mother. This in turn has resulted in many black women developing a higher sense of entrepreneurship, which is borne out by the fact that they tend to fall into the top student bracket.

There has also been a steady increase in the number of women enrolling for the SBMP. Whereas there was only one woman on the first programme, there were five, seven and six women respectively in the ensuing years.

This means that between $9 \%$ and $15 \%$ of SBMP students are women, compared with less than $2 \%$ on other SBL programmes.

\section{Participants' progress after completion of the SBMP}

Four of the 20 successful candidates in the 1975/6 SBMP were promoted to managerial positions by the organizations for which they work.

\section{Further education}

Three of the first SBMP class have since enrolled for the SBL's Management Development Programme (MDP), a one-year middle management course, run on the same lines as the SBMP, but on a considerably higher level.

Thirty per cent of the 1976/77 group enrolled for the 1978/79 MDP course.

\section{Group projects}

Group projects in the SBMP take up most of the participants' study time in the sense that group members have to do a lot of research. These projects are, however, of great value in studying all the subject areas involved in developing a business plan. The projects do not, therefore, detract from study time, but do in fact oblige the students to study more in order to apply the knowledge to a live project. Such projects require dedicated application and research, and, in doing this, the participants are brought into contact with a wide spectrum of business people. The groups do not only meet venture capitalists, bankers and development corporations, but also the general public - their potential customers.

Although most of the projects had reached an advanced stage of development at the end of the study period, many could not be implemented because for a number of reasons: - The programme was launched at a time when inflation was beginning to spiral and the economy was going into a recession.

- Lack of venture capital, or if this was available, there was no collateral.

- Political problems related to the control of black business, mobility of blacks, group areas legislation, and a host of other administrative problems.

The above problems were obstacles to bringing most of the projects to fruition. Despite these problems, a number of projects were implemented and new businesses were started, or existing ones expanded. In the 1975/76 programme two projects were implemented, namely a Supermarket and a Dry Cleaning factory. Although these were existing businesses, they were reorganized and expanded. Of the projects investigated by students in the 1976/77 programme only one was implemented. This was a school uniform distribution undertaking. It will be remembered that this was a very difficult economic period. Following the third programme that is, $1977 / 78$, four projects are in the process of taking off. These projects are: 
Tyre retreading - negotiations for franchizing are in progress.

Coffin manufacturers - A company has been formed and manufacturing is done in the back-yard. Negotiations for industrial sites are bogged down by government regulations.

Brick-making - Since the project will be based in a black state, and will serve a real and existing need, nothing prevents it from being realized. The group will in due course register a company.

Shopping complex-Construction has started and operations should begin this year.

An interesting observation on the development of the projects is the fact that whereas they started off as service businesses in the first programme, they gradually moved to intermediate technology, manufacturing rather than distributing goods on behalf of others.

Spin-offs from the projects in particular and the programme in general, are:

- Several of the owner/managers have been able, through their newly acquired knowledge of planning and estimating, to expand their small businesses or branch out into related businesses.

- All of the participants state that completing the course has given them much more confidence in their own abilities to compete in the business world and to manage uncertainty and risk.

- The amount of environmental scanning and research into the market place and technologies of which they were hitherto unaware, which is required from participants for their projects, has enabled them to recognize new business opportunities.

\section{Conclusion}

Although many of the legal, finanical and cultural restrictions, which have hampered the development of black businesses in South Africa in the past have already been removed, and more are about to disappear, there still remains perhaps the most restrictive of all - lack of proper training in management and entrepreneurship. Through such programmes as the SBMP, and the Small Business Advisory Bureau, being planned by the SBL, the SBL hopes to develop a cadre of black entrepreneurs in Southern Africa who will not only be able to run their businesses well, but will also engage in business expansion programmes and exploit new opportunities to enhance their economic and social standing and well-being. In this way they could also serve and help to develop their own communities.

\section{References}

1 STIFEL, L.D. et al, 1977. Education and Training for Public Sector Management in Developing Countries, Special Report of the Rockefeller Foundation.

2 SCHUCTER, A. 1973. In: Loe, R.F., 1973. The Setting for Black Business Development, New York State School of Industrial and Labour Relations, Cornell Univesity, p 62-63.

3 LEE, R.F., 1973. The Setting for Black Business Development, Comell University, New York, $\mathrm{p} 32$.

4 The course is structured on and largely based on Small Business Management, Training Research and Development Station, Department of Manpower and Integration, Saskatchewan.

5 SMIT, G.J., 1978. Development of the Managerial Potential of South African Women, MBL Dissertation, University of South Africa, p. 101. 